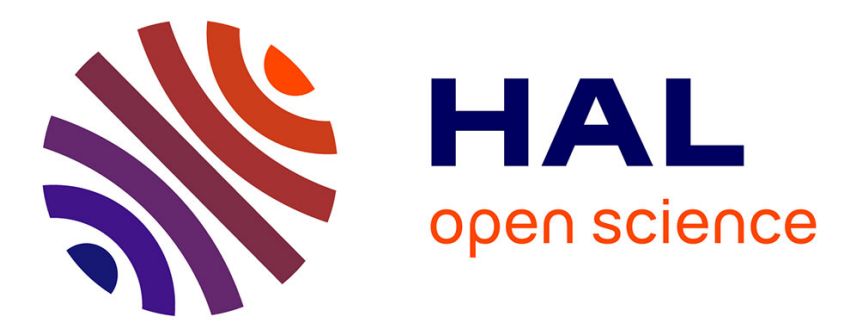

\title{
Investigating the Swelling Pressure of Compacted Crushed-Callovo-Oxfordian Claystone
}

Chaosheng Tang, Anh Minh A.M. Tang, Yu-Jun Cui, Pierre Delage, Christian Schroeder, Emmanuel de Laure

\section{- To cite this version:}

Chaosheng Tang, Anh Minh A.M. Tang, Yu-Jun Cui, Pierre Delage, Christian Schroeder, et al.. Investigating the Swelling Pressure of Compacted Crushed-Callovo-Oxfordian Claystone. Physics and Chemistry of The Earth, 2011, 36 (17-18), pp.1857-1866. 10.1016/j.pce.2011.10.001 . hal-00655750

\section{HAL Id: hal-00655750 \\ https://hal-enpc.archives-ouvertes.fr/hal-00655750}

Submitted on 2 Jan 2012

HAL is a multi-disciplinary open access archive for the deposit and dissemination of scientific research documents, whether they are published or not. The documents may come from teaching and research institutions in France or abroad, or from public or private research centers.
L'archive ouverte pluridisciplinaire HAL, est destinée au dépôt et à la diffusion de documents scientifiques de niveau recherche, publiés ou non, émanant des établissements d'enseignement et de recherche français ou étrangers, des laboratoires publics ou privés. 
${ }^{1}$ School of Earth Sciences and Engineering, Nanjing University, Hankou Road 22, Nanjing, China 6 (tangchaosheng@nju.edu.cn)

${ }^{2}$ Ecole des ponts - ParisTech, U.R. Navier/CERMES, 6-8 av. Blaise Pascal, Cité Descartes,

877455 MARNE-LA-VALLEE, France (tang@cermes.enpc.fr; yujun.cui@enpc.fr;

$9 \quad$ delage@cermes.enpc.fr; delaure@cermes.enpc.fr $)$

${ }^{3}$ ANDRA, 92298 Châtenay-Malabry Cedex, France (Christian.Schroeder@andra.fr)

Corresponding author:

25 Prof. Yu-Jun CUI

26 Ecole des Ponts ParisTech

27 6-8 av. Blaise Pascal, Cité Descartes, Champs-sur-Marne

2877455 Marne-la-Vallée cedex 2

29 France

31 Email : yujun.cui@enpc.fr 


\section{Abstract}

This paper presents an experimental study on the swelling pressure of heavily compacted crushed Callovo-Oxfordian (Cox) claystone at a dry unit mass $\rho_{d}=$ $2.0 \mathrm{Mg} / \mathrm{m}^{3}$ using four different methods: constant-volume, swell-reload, zero-swell and adjusted constant-volume method. Results show that the swelling pressure varies in the range of 1-5 MPa and depends significantly on the test method. From the constant-volume tests, it is observed that the swelling behaviour during wetting is a function of the suction and depends on both the hydration paths and wetting conditions (e.g. vapour-wetting or liquid-wetting). The swelling pressure decreases significantly with saturation time. To identify the microstructure changes of specimens before and after wetting, mercury intrusion porosimetry (MIP) and scanning electron microscopy (SEM) tests were performed. It is observed that, after wetting, the large inter-aggregate pores observed in the as-compacted specimen are no longer apparent; the whole pattern is characterized by a general swell of hydrated clay particles, rendering the soil more homogeneous. Results from MIP indicated that wetting caused a significant reduction of the entrance diameter of the dominant inter-aggregate pores from 2.1 to $0.5 \mu \mathrm{m}$ whereas intra-aggregate pores were not significantly influenced.

Keywords: crushed Callovo-Oxfordian claystone; swelling pressure; hydration path; microstructure; suction; laboratory tests.

\section{Introduction}

Deep clay or claystone formations are considered as potential host rock for radioactive waste disposal in many countries such as Belgium, Germany, France, Japan and Switzerland. In order to ensure the overall safety of the storage system, it is of prime importance to develop a good understanding of the clay properties involved for different time scales: i.e. during construction of the repository as well as its long-term isolation performance (Landais and Aranyossy 2007). In addition to the coupled thermo-hydro-mechanical behaviour of the host rock, the engineering properties of backfilling/sealing materials are also an important issue to investigate because these materials play a critical role in reducing migration of water, gas and radionuclides to an acceptable low level.

In the past decades, bentonite has been widely studied as backfilling and sealing material because of its low permeability, adequate self-sealing potential and high water retention capacity (Marcial et al. 2002, Lloret et al., 2003; Tang and Cui, 2005; Hoffman et al., 2007; Tang et al., 2008a and 2008b; etc.).

The use of crushed excavated COx claystone as a possible backfilling/sealing material to isolate the waste canisters from the concrete retainement and the access gallery has been considered as a possible alternative by the French Radioactive Waste Management Agency (ANDRA) in the Underground Research Laboratory (URL) excavated at a depth of 445-490 m in Callovo-oxfordian (COx) claystone at Bure 
(Eastern France, Lebon and Mouroux, 1999), The main advantages of this option are:

(i) recycling excavated $\mathrm{COx}$ claystone as sealing material reduces the negative environmental impact; (ii) replacing commercial bentonite by excavated $\mathrm{COx}$ claystone reduces financial costs; (iii) there is no problem of mineralogical and physico-chemical incompatibility between the host rock and the backfilling/sealing material.

It is expected that once the backfilling/sealing material is installed, pore water from the host rock will infiltrate the compacted claystone, thereby causing it to expand and develop swelling pressure under nearly constant volume conditions. This swelling pressure should be high enough to ensure sealing efficiency. Also, the swelling pressure of the hydrated compacted claystone should not exceed the in-situ principal minor stress (about $7 \mathrm{MPa}$ - after Wileveau et al., 2007) so as to ensure satisfactory mechanical stability. It is therefore important to study in detail the swelling properties of the compacted crushed claystone. Since the pre-compacted backfilling/sealing blocks will be subjected to hydromecanical conditions once installed, the study of the swelling behaviour must be conducted under different boundary conditions. In this investigation, four methods, namely a constant-volume method carried out in a specifically designed new cell, a swelling-reloading method, a zero-swell and an adjusted constant-volume method were respectively employed to evaluate the swelling pressure of highly compacted crushed COx claystone in the laboratory. Different hydro mechanical boundary conditions were applied to the specimens to simulate the possible in-situ confinement and wetting process. In addition, long-term tests were carried out to study time effects (Delage et al. 2006). The microstructure changes of the specimens before and after wetting were also analyzed by performing mercury intrusion porosimetry (MIP) and scanning electron microscopy (SEM) tests.

\section{Material}

The Callovo-Oxfordian (COx) claystone from the Bure site considered here contains $40-45 \%$ clay minerals (illite-smectite interstratified minerals being the dominant clay minerals), 30\% carbonates and 25-30\% quartz and feldspar. The in-situ water content is $2.8-8.7 \%$, the wet unit mass is $2.32-2.61 \mathrm{Mg} / \mathrm{m}^{3}$ and the specific gravity is 2.70 (Fouché et al. 2004).

COx claystone blocks obtained during excavation were air-dried and crushed to powder at an initial water content of $2.8 \%$. The grain size distribution of the powder determined by dry sieving is presented in Fig.1. In order to obtain a higher water content, a quantity of powder was put in a hermetic chamber where the relative humidity was maintained at $91.3 \%$ at a temperature of $20^{\circ} \mathrm{C}$ (corresponding to a suction of $12.6 \mathrm{MPa}$ ) by allowing vapour circulation of saturated $\mathrm{ZnSO} 4.7 \mathrm{H} 2 \mathrm{O}$ solution (Delage et al. 1998). Once equilibrium was reached, the powder water content was found to be $6.4 \%$.

\section{Experimental methods and test program}

To determine the soil swelling pressure in the laboratory, the COx powder was first compacted statically to a dry unit mass of $2.0 \mathrm{Mg} / \mathrm{cm}^{3}$ in an oedometer cell. The 
swelling pressure of the compacted COx sample was then measured using four methods: constant-volume, swell-reload, zero-swell and adjusted constant-volume method respectively. Details of each method are presented below and the test program is summarized in Table 1.

\subsection{Constant-volume method}

Traditionally, constant volume tests are performed based on the strain-controlled technique (Azam et al. 2000; Tripathy et al. 2004; Hoffmann et al. 2007). There are two strain-controlled techniques for constant volume conditions. The first consists in applying a small incremental load on the specimen in the oedometer cell and to prevent, when the specimen is wetted, any vertical expansion by progressively loading the sample. Once no more expansion is observed upon wetting, the final total load applied is defined as the swelling pressure of the soil (Al-Mhaidib 1998; Al-Shamrani and Dhowian 2003; Thompson et al. 2006; Villar and Lloret 2008). The second method consists in preventing any vertical movement by using a rigid reaction frame and in measuring the swelling pressure with a force transducer (Lloret et al. 2003; Aiban 2006; Hoffmann et al. 2007; Tang et al. 2008). In reality, it is difficult to maintain a strictly constant volume condition - the measured swelling pressure is influenced by many factors. In the former strain-controlled technique, each incremental load corresponds to a soil compression, giving rise to changes in soil microstructure that affect the swelling pressure. The swelling pressure determined is therefore very sensitive to the load increment and the loading rate. Moreover, in order to bring the specimen back to its initial volume, it is necessary to overcome the friction between soil specimen and oedometer ring; that results in over-estimation of the swelling pressure. In the latter constant volume technique, Tang et al. (2008) found that the "constant volume" condition depends significantly on the stiffness of the load cell and of the whole device. The corresponding swelling pressure error can reach 1-2 $\mathrm{MPa}$. Pejon and Zuquette (2006) pointed out that very small changes in specimen height (e.g. a strain of $0.5 \%$ ) would lead to significant swelling pressure changes (e.g. 45-60\%). Thus, the measurement of swelling pressure by the methods mentioned above should be regarded as indirect measurements only. Up to now, owing to difficulties related to testing devices, data on direct measurement of the swelling pressure under constant volume conditions are scarce. For this reason, a new constant volume cell has been developed that allows the swelling pressure to be measured without any strain adjustment and any effect of the stiffness of the testing device.

\subsubsection{View of the cell}

A schematic view of the new constant volume cell developed is presented in Fig. 2. The pressure sensor was used to measure the swelling pressure. It was fixed inside the upper part of the cell and put into direct contact with the top surface of the specimen. The cylindrical soil specimen $(70 \mathrm{~mm}$ in diameter and $10 \mathrm{~mm}$ in height) was placed inside the middle part of the cell. A porous stone was placed at the bottom and in contact with the soil specimen. Two inlets in the lower part of the cell ensured the 
circulation of liquid water or relative humidity-controlled vapour for suction control. Two outlets ensured the flow of water/vapour from the top surface of the soil specimen.

\subsubsection{Detail about the pressure sensor}

As mentioned above, most constant-volume tests use common compression load cells for the measurement of soil swelling pressure (Imbert and Villar 2006; Pejon and Zuquette 2006; Thompson et al. 2006). These load cells present significant drawback related to the induced strain by the soil swelling, especially when highly expansive soils are tested (Pejon and Zuquette 2006; Tang et al. 2008). This strain leads to a significant underestimation of the measured swelling pressure.

In this study, a BER-A-58S pressure sensor was used in the constant volume cell (Fig. 3a). The working pressure is $5 \mathrm{MPa}$; the diameter of the working surface is $73 \mathrm{~mm}$. The main difference from a standard pressure sensor (Fig. 3b) is that a void space filled with mercury was machined below the diaphragm. Mercury is used so as to minimize the deformation under external pressure. In the case of a standard pressure sensor (Fig. 3b), obviously, much larger diaphragm deformation can be expected.

\subsubsection{Test procedure}

In the constant volume test, the air-dried COx powder was statically compacted in an oedometer cell to a dry unit mass of $2.0 \mathrm{Mg} / \mathrm{cm}^{3}(70 \mathrm{~mm}$ in diameter and a $10 \mathrm{~mm}$ in height). After compaction, the soil specimen was taken out of the oedometer cell and introduced into the constant volume cell. The three parts of the cell (top, middle and bottom) were then mounted together using screws (Fig. 2).

The experimental setup is shown in Fig. 4. A pump was used to ensure the relative humidity-controlled vapour circulation at the bottom of soil specimen for suction control. During the test, changes in vertical stress were recorded automatically by a data logging system. Room temperature was maintained at $20 \pm 0.5^{\circ} \mathrm{C}$.

Five specimens were compacted and subjected to different suctions $(s=57,38,9$ and $0 \mathrm{MPa}$, see also Table 1) by using the vapour equilibrium technique (Tang and Cui 2005). To apply zero suction, distilled water was injected under a constant pressure of $15 \mathrm{kPa}$ from the bottom inlet of the cell to saturate the specimen. The hydration path for each test was chosen as follows.

In test $\mathrm{T} 1$, an initial suction of $57 \mathrm{MPa}$ was first applied, followed by $38 \mathrm{MPa}$, $9 \mathrm{MPa}$ and $0 \mathrm{MPa}$ suctions. Note that to study possible aging effects in the swelling behaviour, the changes in swelling pressure at $0 \mathrm{MPa}$ suction were monitored for more than one year.

Test T2 was intended to evaluate the repeatability of the employed technique. After stabilization of the selling pressure under an initial suction of $57 \mathrm{MPa}$, a subsequent wetting at $38 \mathrm{MPa}$ suction was conducted.

In test $\mathrm{T} 3$, an initial suction of $38 \mathrm{MPa}$ was applied, followed by a full saturation using distilled water. 
In test $\mathrm{T} 4$, a $9 \mathrm{MPa}$ initial suction was applied. When equilibrium was reached, zero suction was imposed by using distilled water. In test T5, the soil specimen was directly wetted using distilled water.

\subsection{Swell-reload method}

Test T6 was performed according to the swelling-reloading method (Table 1). The air-dried COx powder was statically compacted to a dry unit mass of $2.0 \mathrm{Mg} / \mathrm{cm}^{3}$ in an oedometer cell (diameter $38 \mathrm{~mm}$, height $10 \mathrm{~mm}$ ). After compaction, the oedometer cell was placed on a high-pressure oedometer frame (see Marcial et al. 2002 for more detail) and the specimen was allowed to swell freely until stabilization under a constant vertical stress of $0.1 \mathrm{MPa}$. It was then loaded in steps $(24$ hour interval between each step) to bring the void ratio back to the initial value. The corresponding vertical stress is the swelling pressure.

\subsection{Zero-swell method}

As in test T6, the soil specimen was compacted at a dry unit mass of $2.0 \mathrm{Mg} / \mathrm{cm}^{3}$ in the oedometer cell (Test T7). It was then wetted on a high-pressure oedometer frame under a vertical stress of $0.1 \mathrm{MPa}$ using distilled water. Once the specimen started to swell, the vertical load was increased so as to prevent any vertical swelling. During this process, the maximum swell allowed was $20 \mu \mathrm{m}$ - corresponding to a vertical strain of $0.1 \%$ ). Once the swelling was complete, the total applied load was recorded and defined as the swelling pressure of the soil. Note that this method has been widely employed internationally in determining the soil swelling pressure (Al-Mhaidib 1998;

\subsection{Adjusted constant-volume method}

A triaxial press (Fig. 5) was used to apply the adjusted constant-volume method. The experimental set-up is mainly composed of a piston, a load cell and an oedometer cell mounted on an adjustable steel loading frame. The pressure applied to the specimen was controlled by adjusting the level of the displacement shaft. The air-dried COx powder was statically compacted to a dry unit mass of $2.0 \mathrm{Mg} / \mathrm{cm}^{3}$ and unloaded to different axial stress levels. At a given initial stress level, distilled water was injected by using a volume/pressure controller that was connected to the oedometer. During this process, the "constant-volume" condition was ensured by fixing the displacement shaft and, if necessary, manually adjusting it according to the monitoring of the displacement transducer (electronic digital micrometer). The resulted swelling pressure was measured using a load cell of $5 \mathrm{kN}$ capacity. Three tests were performed following this method (T8, T9 and T10; Table 1). Tests T8 and T9 were performed on air-dried specimens $(w=2.8 \%)$, test T10 on a wetted specimen $(w=6.4 \%)$. Note test T8 was replicated with two specimens (T8-1 and T8-2) wetted under an initial axial stress of $0.5 \mathrm{MPa}$. T9 and T10 were wetted under a higher initial axial stress of $7 \mathrm{MPa}$.

\subsection{Microstructure investigation}


Microstructural changes of the specimens before and after wetting under constant volume conditions were observed by performing MIP and SEM tests. Freeze-drying technique was employed to dehydrate the soil samples with minimum disturbance (see Delage et al., 2006 for more details). Two samples were tested: one at the 'as-compacted' state and another after wetting under an initial axial stress of $0.5 \mathrm{MPa}$, obtained from test T8-2.

\section{Results}

\subsection{Results from constant-volume tests}

The results from the constant-volume tests using the new constant-volume cell (Fig. 2) under controlled suction are presented in Fig. 6. It can be seen during the progressive wetting by applying successively the suctions of 57, 39, 9 and $0 \mathrm{MPa}$ (test T1, Fig. 6a), the swelling pressure increased to $0.17,0.30,0.81$ and $1 \mathrm{MPa}$, respectively. Note that the time needed to reach the equilibrium was about 15 days at $s=57 \mathrm{MPa}, 22$ days at $s=39 \mathrm{MPa}$ and 30 days at $s=9 \mathrm{MPa}$.

The results of tests T1 and T2 wetted under the same suctions (57 and $39 \mathrm{MPa}$ ) are presented in Fig 6b. The two curves are quite similar, indicating a good repeatability of the test and validating the test procedure.

The results from tests T3 and T4 are presented in Fig. 6c. In test T3, at $39 \mathrm{MPa}$ suction, the swelling pressure is about $0.24 \mathrm{MPa}$. At saturation, the swelling pressure increased up to $1 \mathrm{MPa}$. In test $\mathrm{T} 4$, the swelling pressure measured by wetting directly at $9 \mathrm{MPa}$ suction is about $0.54 \mathrm{MPa}$. It is interesting to note that when zero suction was applied, the same swelling pressure (1 MPa) was obtained as in test T3.

Fig. $6 \mathrm{~d}$ shows the swelling pressure changes when directly hydrating under zero suction (test T5). A final value of $0.82 \mathrm{MPa}$ was measured.

Note that in tests T1 to T5, when zero suction was applied by injecting distilled water, the swelling pressure increased quickly to a peak value followed by a slight decrease and reached finally a plateau of stabilization. This phenomenon was not observed under controlled-suction conditions.

Table 2 summarizes the swelling pressures of some typical bentonite-based backfilling materials after saturation at different dry densities. The values were also determined by the "constant-volume" method. It should be noted that the "constant-volume" was not performed in a constant volume cell as developed in the present investigation, but following the traditional procedure described previously. As expected, the swelling pressures (Table 2) are generally much higher than those of crushed COx arigillite (0.8-1.1 MPa, Fig. 6), even though the dry densities of these bentonite-based backfilling materials are lower than $2.0 \mathrm{Mg} / \mathrm{m}^{3}$ of crushed $\mathrm{COx}$ arigillite. This can be explained by the high smectite fraction in bentonite-based backfilling materials.

\subsection{Results from swell-reload and zero-swell tests}

Fig. 7 shows the results from the swelling-reloading test (T6) and the zero-swell test (T7). Under a low vertical stress of $0.1 \mathrm{MPa}$, a quick free swell occurred in test T6, stabilizing at $6.8 \%$ after a 98 -hour period of saturation (see Fig. 7a). Additional 
loadings induced a progressive compression of the soil specimen as shown by the stress-strain curve shown in Fig. 7b. It can be seen that a stress of about $2.2 \mathrm{MPa}$ was required to bring the specimen back to its initial void ratio. This value is a measure of the swelling pressure. It is seen to be much higher than the value determined from the constant-volume test (0.82 MPa, T5).

The curve showing vertical strain changes of the zero-swell test (T7) is clearly divided into two parts, one with a constant value equal to zero and the other with increase in vertical strain (Fig. 7a). Deeper examination shows that the first part does not correspond strictly to a zero value. A variation of less than $0.1 \%$ was recorded that was the maximum value allowed during the test. Fig. $7 \mathrm{~b}$ shows that the maximum stress applied to maintain the constant volume is about $1 \mathrm{MPa}$, further loading resulting in sample compression. The value of $1 \mathrm{MPa}$ is by definition the swelling pressure determined by the zero-swell test (T7). Comparison between the two compression curves at high stresses (vertical stress higher than $4 \mathrm{MPa}$ ) shows that the behaviour in tests T6 and T7 is the same (Fig. 7b).

\subsection{Results from adjusted constant-volume test}

Fig. 8 shows the changes in vertical stress and in void ratio in tests T8-1, T8-2, T9 and T10. In test T8-1, the specimen was wetted under a low initial vertical stress of $0.5 \mathrm{MPa}$. A large change in void ratio was observed ( $e$ increased from 0.358 to 0.394 after $60 \mathrm{~h}$, corresponding to a volumetric strain of $2.65 \%$, Fig $8 \mathrm{a}$ ). Only a slight increase in vertical stress $\sigma_{v}$ was observed during this period, from 0.67 to $0.87 \mathrm{MPa}$. The "constant-volume" conditions were then adjusted by moving the displacement shaft and reducing $e$ as a consequence to its initial value. At equilibrium, $e$ was equal to 0.352 and $\sigma_{v}$ to $3.5 \mathrm{MPa}$. The large change in void ratio observed can be explained by the existence of a possible small gap between the piston and the load cell (Erreur ! Source du renvoi introuvable.5) that could not be avoided under low stress. A similar procedure was applied in test T8-2 but with more care paid to the system before flooding in order to minimise any similar gap. The results obtained show a slight change in void ratio corresponding to a volumetric strain lower than $0.15 \%$ (Fig. 8 a). By contrast, $\sigma_{v}$ increased quickly and stabilized at a value of $4.2 \mathrm{MPa}$ after 70 hours. Note that the values of swelling pressure identified in tests T8-1 and T8-2 are about twice that obtained by the swelling-reloading method (T6) and four times that obtained by the constant-volume method (T5) and zero-swell method (T7).

In tests T9 (Fig. 8b) and T10 (Fig. 8c), the soil specimens were wetted under the same initial high vertical stress of 7.0 MPa from different initial water contents (T9, $w=2.8 \%$; T10,w $=6.4 \%$ ). The evolution of the vertical stress $\sigma_{v}$ with hydration time is similar: $\sigma_{v}$ decreases first and tends to stabilization. In test $\mathrm{T} 9, \sigma_{v}$ stabilized at 5.3 MPa, a slightly higher value than that of test T10 (3.8 MPa). During the whole hydration period, $e$ remained almost constant in both tests T9 and T10 (Fig. 8b and Fig.8c respectively), indicating that the "constant volume" conditions were satisfactory ensured.

\subsection{Microstructure observation}


For further analysis of hydration and swelling behaviour, microstructure changes before and after wetting were investigated based on the SEM and MIP tests. Two specimens were studied: an as-compacted specimen at $\rho_{d}=2.0 \mathrm{Mg} / \mathrm{m}^{3}$, and a specimen from test T8-2 (after wetting under an initial vertical stress of $0.5 \mathrm{MPa}$ in constrained-volume condition). The results are shown in Figs. 9 and 10. In the as-compacted specimen (Fig. 9a), large aggregates can be clearly observed, together with large inter-aggregate pores of several micrometers in diameter. By contrast, for the specimen wetted under constrained-volume condition, a quite different overall image is observed (Fig. 9b). Indeed, although the dry unit mass is the same $\left(2.0 \mathrm{Mg} / \mathrm{m}^{3}\right)$, aggregates are no longer evident and the picture is characterized by a general swell of the hydrated clay particles, rendering the global microstructure more homogeneous. Moreover, the large pores observed in the as-compacted specimen disappeared. Most inter-aggregates pores are less than $3 \mu \mathrm{m}$ in diameter. This is obviously the consequence of (i) swelling of clay particles, (ii) sub-division of aggregates and (iii) the filling of inter-aggregate pores (Ye et al. 2009).

The pore size distribution curves exhibit a typical bimodal porosity in both specimens (Fig. 10a). This phenomenon is consistent with other works carried out on compacted soils (Ahmed et al. 1974, Delage et al. 1996, Delage et al., 2007; Tarantino and De Col, 2008). Comparison between the curves of the two specimens shows that wetting decreases the modal size of inter-aggregate pores from 2.1 to $0.5 \mu \mathrm{m}$, in agreement with the SEM observation (Fig. 9). Changes in intra-aggregate pores $(<0.1$ $\mu \mathrm{m}$ diameter) are found to be insignificant. This is probably due to the constrained-volume condition. The variations of intruded mercury void ratio (ratio of intruded mercury volume with respect to solid volume) are evidence of the same phenomenon (Fig. 10b). During wetting, the population of inter-aggregate pores of the as-compacted sample defined by the inflection point on the curve at $2.1 \mu \mathrm{m}$ was displaced leftwards with an inter-aggregates pore population of inter-aggregate pores defined by an inflection point at $0.5 \mu \mathrm{m}$.

\section{Discussions}

\subsection{Effect of suction and hydration path}

Saiyouri et al. (1998, 2000, 2004) studied two compacted smectites (FoCa and MX80) and suggested, following Mooney et al. (1952) and others, that the hydration of clay minerals was governed by the discrete and progressive placement of water molecule layers along the clay sheets within the clay particle. The number of water molecule layers varies from zero in the dry state to four in the fully hydrated state. As described also in Delage (2007), the swelling behaviour of bentonites is related to two combined processes: i) the progressive absorption of successive layers of water molecules in the interlayer spaces inside the particles enlarges the interlayer distance; ii) the sub-division of particles into thinner ones leads to larger inter-particles pores inside the aggregates. Chipera et al. (1997) and Likos (2004) also found that the absorbed water layers in the interlayer space increase with ambient relative humidity $\mathrm{RH}$ increase. In this investigation, specimens $\mathrm{T} 1$ to $\mathrm{T} 5$ were wetted by decreasing suction in the constant-volume cell. The expansion of soil volume was constrained 
and the swelling behaviour hence resulted in an increase in swelling pressure.

2 According to the results shown in Fig. 6, the stabilized swelling pressure is a function

3 of the levels of applied suction: the lower the suction the higher the swelling pressure.

4 This is mainly because the decrease of suction gives rise to an increase in absorbed

5 water layers along clay sheets and a decrease in the number of stacked clay sheets.

6 When suction was decreased from 57 to $9 \mathrm{MPa}$, the corresponding RH was increased

7 from 66 to $93.7 \%$ at $20{ }^{\circ} \mathrm{C}$ temperature. According to Chipera et al. (1997), the

8 maximum absorbed water layer in the tested $\mathrm{COx}$ claystone may reach 2 layers.

Table 3 summarizes the swelling pressure values obtained in the different tests and at different suctions. It is interesting to note that, whatever the suction value, the measured swelling pressure in test T1 is always higher than that of T3, T4 and T5. In addition, the values from tests $\mathrm{T} 3$ and $\mathrm{T} 4$ at zero suction are also higher than that from test T5. These observations show that the swelling behaviour under the constant volume condition is hydration path-dependent. A progressive hydration in steps from a given suction value to lower ones would result in a higher swelling pressure when compared to a direct hydration path to the final suction. A possible reason for this could be that the soil hydration would be more homogenous when suction is progressively decreased in steps.

The results presented in Fig. 6 show that the time needed for the swelling pressure stabilization is also hydration path-dependent with a shorter time required to reach stabilization with the direct path than with the step path. This behaviour may be due to the distinct rates of water vapour migration that intervene within the soil according to the wetting paths followed. The rate of water vapour migration is governed by the suction gradient between the soil specimen and the bottom of the cell where the suction was imposed; it increases with increasing suction gradient (Push 1982). When the compacted air-dried COx claystone specimens (initial suction estimated at 100 $\mathrm{MPa}$ according to the ambient relative humidity comprised between 55 and $60 \%$ and by neglecting any effect due to compaction or density changes) were gradually wetted by increasing the relative humidity, water vapour was absorbed and moved inside the specimen under the suction gradients. Normally, water vapour was firstly absorbed in small inter-particle or inter-clay sheets pores where the suction potential was relatively high. But when wetting continued, more and more water was absorbed by soil specimen, the corresponding suction gradient gradually decreased and finally reached equilibrium. During this process, the rate of vapour migration also decreased progressively to zero. For test T1, the specimen was wetted in steps, the suction gradient in each step was much lower than that in the case of direct path as tests T3 and T4 and the corresponding water vapour migration rate in test $\mathrm{T} 1$ was therefore slower than that in tests $\mathrm{T} 3$ and $\mathrm{T} 4$.

The different swelling behaviours observed before and after water flooding in Fig. 6 may be attributed to the different hydration process involved in vapour-wetting and 41 in liquid-wetting. In the hydration process of vapour-wetting described above, the water vapour was initially absorbed in intra-aggregate pores. By contrast, during water-wetting, water firstly entered in the inter-aggregate pores. As a result, 44 aggregates begun to expand and sub-divide, leading to a sudden increase in swelling 
pressure. Meanwhile, the wetting process weakened the aggregates mechanically, resulting in the deformation and rearrangement of the aggregates. This explains the drop of the measured swelling pressure. The SEM and MIP results shown in Figs. 9 and 10 confirm this explanation: the size of inter-aggregate pores decreased and the soil microstructure became more homogenous after hydration.

Unlike the evolution pattern identified in this study for the swelling pressure, the results obtained by Push (1982), Komine and Ogata (1994) and Imbert and Villar (2006), show a pattern in which the swelling pressure first increases quickly up to a peak, then decreases towards a minimum to increase again and finally reach a constant value. This difference may be due to the different mineral compositions of the soils tested. In the tests of Push (1982), Komine and Ogata (1994) and Imbert and Villar (2006), bentonite or bentonite mixtures containing high proportions of montmorillonite were used. In such materials, the swelling behaviour due to hydration finally prevails over the collapse of the inter-aggregates pores, leading to a swelling pressure increase after a short-term decrease. For the COx claystone tested here illite-smectite interstratified mineral was the dominant clay mineral. As hydration proceeds, the further swelling of clay particles is apparently not strong enough to compensate for the fabric collapse and does not result in a second increase in swelling pressure. This also explains the constant decrease of swelling pressure with hydration time after the peak (Fig. 6).

\subsection{Effect of the test method}

The experimental results obtained in this study clearly show that swelling pressure measurements are strongly test dependent. The swelling-reloading method gave higher values than the constant-volume method and the zero-swell method. This is consistent with observations made by other researchers. For instance, Tisot and Aboushook (1983) and Thompson et al. (2006) reported that the swelling pressure measured by the zero-swell method was about $1 / 3$ of that by the swelling-reloading method. Results reported by Al-Shamrani and Dhowian (2003) also indicated that the swelling pressure measured by the swelling-reloading method was higher than that obtained with the zero-swell method. The reason is that, in the swelling-reloading method (T6), the specimen was allowed to swell by absorbing water under a relative low load of 0.1 MPa. In constant-volume (T1 to T5) and zero-swell method (T7), the specimens were not allowed to swell, so that hydration of clay particles was therefore constrained. In the former case, an overall hydration can occur, giving rise to a high swelling pressure value. By contrast, in the latter case, hydration could be more heterogeneous, resulting in a lower swelling pressure. In addition, the difference in the observed swelling pressures can be also due to the structure modification occurring during the free swell phase, as well as to the friction developed between specimen and oedometer cell during the re-loading phase. Nagaraj et al. (2009) attributed the variations of the measured swelling pressure to the heterogeneous moisture distribution over the thickness of the specimen. By introducing several vertical sand drains in the specimen, they found that the differences in the swelling pressure by the swelling-reloading method and the zero-swell method were reduced; both the swell 
and swelling pressure of the tested specimens have been improved. They therefore concluded that the measured swelling pressure value through a one-dimensional oedometer test may not be an intrinsic property of the soil. Since the results from tests T6 and T7 shown in Fig. 7 are similar during the compression in saturated state, this suggests that the effect of swelling on the later compression is not significant.

When comparing the results of the constant-volume method (Fig. 6) and the zero-swell method (T7 in Fig. 7 b), it is observed that the measured swelling pressures are close, about $1 \mathrm{MPa}$. The swelling pressure measured by the constant-volume cell developed by the authors is therefore consistent with the value obtained by the standard method, confirming the validity of the developed constant-volume cell for swelling pressure measurement.

When comparing the results from tests T6 (swell-reload method, Fig. 7) and T8 (adjusted constant-volume method, Fig. 8a), it is observed that the swelling pressure from test T8 is higher than that from test T6. Actually, the main difference between test T6 and test T8 is the loading procedure. In test T6, loading was performed after the specimen was hydrated completely with the clay particles mechanically much weakened. Nevertheless, in test T8, loading was performed during wetting where the specimen was not saturated. Therefore, higher compaction energy should be applied to overcome the specimen skeleton strength. In addition, the higher swelling pressure obtained by the adjusted constant-volume tests can be also linked to the rapid loading generated during wetting. The time was therefore insufficient for water drainage or redistribution.

\subsection{Effect of the initial vertical loading}

Results shown in Fig. 8 indicate that the swelling behaviour of compacted crushed COx claystone depends on the initial applied vertical stress. Indeed, wetting induced an increase of $\sigma_{v}$ when the initial vertical stress was low (0.5 MPa, Fig. 8a) and a decrease of $\sigma_{v}$ when the initial vertical stress was high (7 MPa, Figs. 8b, c). The changes in swelling pressure of compacted expansive soils upon wetting were also studied by Komine and Ogata (1999) and Lloret et al. (2003) with similar conclusions. The observed phenomenon can be explained based on the double-structure model described by Gens and Alonso (1992), Alonso et al. (1999), Sanchez et al. (2005) and Tang and Cui (2009). On one hand, wetting increases the interlayer distance between clay sheets, resulting in clay aggregates swelling. On the other hand, this weakens the resistance of the macrostructure. When the soil is wetted in a constant volume condition under low initial stress, the first mechanism prevails over the second and an increase in swelling pressure is observed. On the contrary, when the soil is wetted under a high initial stress, the second mechanism prevails: wetting induces collapse of macro-pores and thus decreases the swelling pressure. To some extent, the wetting-induced collapse of macro-pores was also evidenced by the MIP tests: the results in Fig. 10b shows a decrease of the size of the macro-pores family after wetting.

\section{Conclusion}


1 An experimental investigation on the swelling pressure of highly compacted crushed

2 COx claystone (initial dry unit mass $\rho_{d}=2.0 \mathrm{Mg} / \mathrm{m}^{3}$ ) under different boundary 3 conditions was conducted by four test methods. The microstructure of the material 4 before and after wetting was also studied using MIP and SEM techniques. The 5 following conclusions can be drawn:

6 (1) The swelling pressure of the tested COx claystone strongly depends on the test

\section{Acknowledgements}

The authors wish to acknowledge ANDRA (the French Radioactive Waste Management Agency) for its financial support. The views expressed in this paper are those of the authors and do not engage ANDRA in any matter.

\section{References}

Ahmed, S., Lovell, C.W., Diamond, S., 1974. Pore sizes and strength of compacted clay. ASCE Journal of the Geotechnical Engineering Division 100, 407-425.

Al-Mhaidib, A.I., 1998. Swelling behaviour of expansive shales from the middle region of Saudi Arabia. Geotechnical and Geological Engineering 16, 291-307.

Alonso, E.E., Vaunat, J., Gens, A., 1999. Modelling the mechanical behaviour of expansive clays. Engineering Geology 54(1-2), 173-183.

Al-Shamrani, M.A., Dhowian, A.W., 2003. Experimental study of lateral restraint effects on the potential heave of expansive soils. Engineering Geology 69, 63-81.

Aiban, S.A., 2006. Compressibility and swelling characteristics of Al-Khobar Palygorskite, eastern Saudi Arabia. Engineering Geology 87, 205-219.

Azam, S., Abduljauwad, S.N., Al-Shayea, N.A., Al-Amoudi, O.S.B., 2000. Effects of calcium sulphate on swelling potential of an expansive clay. Geotechnical Testing Journal 23, 389-403. 
Chipera, S.J., Carey, J.W., Bish, D.L., 1997. Controlled-humidity XRD analyses: Application to the study of smectite expansion/contraction. In Advances in X-Ray Analysis, Vol. 39, J.V. Gilfrich et al., Eds., 713-721.

Delage, P., 2007. Microstructure features in the behaviour of engineered barriers for nuclear waste disposal. In Experimental Unsaturated Soils Mechanics, Proc Int. Conf. on Mechanics of Unsaturated Soils, 11-32, T. Schanz ed., Weimar, Germany, Springer.

Delage, P., Audiguier, M., Cui, Y.J., Howat, M.D., 1996. Microstructure of a compacted silt. Canadian Geotechnical Journal 33 (1), 150-158.

Delage, P., Howat, M., Cui, Y.J., 1998. The relationship between suction and swelling properties in a heavily compacted unsaturated clay. Engineering Geology 50 (1-2), 31-48.

Delage, P., Marcial, D., Cui, Y.J., Ruiz, X., 2006. Ageing effects in a compacted bentonite:a microstructure approach. Géotechnique 56, 291-304.

Dueck, A., 2008. Laboratory results from hydro-mechanical tests on a water unsaturated bentonite. Engineering Geology, 97: 15-24.

Fouché, O., Wright, H., Le Cléac'h, J.M., Pellenard, P., 2004. Fabric control on strain and rupture of heterogeneous shale samples by using a non-conventional mechanical test. Applied Clay Science $26,367-387$.

Gens, A., Alonso, E.E., 1992. A framework for the behaviour of unsaturated expansive clays. Canadian Geotechnical Journal 29, 1013-1032.

Nagaraj, H.B., Mohammed Munnas, M., Sridharan, A., 2009. Critical evaluation of determining swelling pressure by swell-load method and constant volume method. Geotechnical Testing Journal 32(4), 305-314.

Hoffmann, C., Alonso, E.E., Romero, E., 2007. Hydro-mechanical behaviour of bentonite pellet mixtures. Physics and Chemistry of the Earth 32, 832-849.

Imbert, C., Villar, M.V., 2006. Hydro-mechanical response of a bentonite pellets/powder mixture upon infiltration. Applied Clay Science 32, 197-209.

Komine, H., Ogata, N., 1994. Experimental study on swelling characteristics of compacted bentonite. Canadian Geotechnical Journal 31, 478-490.

Landais, P., Aranyossy, J.F., 2007. Clays in natural \& engineered barriers for radioactive waste confinement. Physics and Chemistry of the earth 32, 1.

Lebon, P. Mouroux, B., 1999. Knowledge of the three French underground laboratory sites. Engineering Geology 52(3-4), 251-256.

Likos, W., 2004. Measurement of crystalline swelling in expansive clay. Geotechnical testing Journal 27, 1-7.

Lloret, A., Villar, M.V., Sanchez, M., Gens, A., Pintado, X., Alonso, E.E., 2003. Mechanical behaviour of heavily compacted bentonite under high suction changes. Géotechnique 53(1), 27-40.

Marcial, D., Delage, P., Cui, Y.J., 2002. On the high stress compression of bentonites. Canadian Geotechnical Journal 39 (4), 812-820.

Maugis P., Imbert, C., 2007. Confined wetting of FoCa clay powder/pellet mixtures: Experimentation and numerical modeling. Physics and Chemistry of the Earth, 32, 795-808.

Mooney, R.W., Keenan, A.C., Wood, L.A., 1952. Adsorption of water vapour by montmorillonite. II. Effect of exchangeable ions and lattice swelling as measured from X-ray diffraction. J. Amer. Chem. Soc. 74, 1371-1374. 
Pejon, O.J., Zuquette, L.V., 2006. Effects of strain on the swelling pressure of mudrocks. International Journal of Rock Mechanics and Mining Sciences 43, 817-825.

Push, P., 1982. Mineral-water interactions and their influence on the physical behaviour of highly compacted Na bentonite. Canadian Geotechnical Journal 19, 381-387.

Sanchez, M., Gens, A., Guimaraes, L.N., Olivella, S., 2005. A double structure generalized plasticity model for expansive materials. International Journal for Numerical and Analytical Methods in Geomechanics 29(8), 751-787.

Saiyouri, N., Hicher, P.Y., Tessier, D., 1998. Microstructural analysis of highly compacted clay swelling. Proc. $2^{\text {nd }}$ Int. Conf. on Unsaturated soils, Beijing: Academic publishers, Vol. 1, 119-124.

Saiyouri, N., Hicher, P.Y., Tessier, D., 2000. Microstructural approach and transfer water modeling in highly compacted unsaturated swelling clays. Mech. Cohesive Frictional Mater 5, 41-60.

Saiyouri, N., Tessier, D., Hicher, P.Y., 2004. Experimental study of swelling in unsaturated compacted clays. Clay Minerals 39, 469-479.

Tang, A. M., Cui, Y. J., 2005. Controlling suction by the vapour equilibrium technique at different temperatures and its application in determining the water retention properties of MX80 clay. Can. Geotech. J. 42 (1), 287-296.

Tang, A.M., Cui, Y.J., Barnel, N., 2008a. Thermo-mechanical behaviour of a compacted unsaturated swelling clay. Géotechnique 58(1), 45-54.

Tang, A.M., Cui, Y.J., Le, T.T., 2008b. A study on the thermal conductivity of compacted bentonites. Applied Clay Sciences 41, 181-189.

Tang, C.S., Tang, A.M., Cui, Y.J., Delage, P., Barnichon, J.D., Shi, B., 2008. On the hydro-mechanical behaviour of a compacted crushed argillite. Proc. Int. Workshop on Unsaturated Soils IWUS 08, Trento, in press.

Tang A.M., Cui Y.J. 2009. Modelling the thermo-mechanical behaviour of compacted expansive clays. Géotechnique 59 (3), 185-195.

Tarantino, A., De Col, E., 2008. Compacted behaviour of clay. Géotechnique 58(3), 199-213.

Thompson, R.W., Perko, H.A., Rethamel, W.D., 2006. Comparison of constant volume swell pressure and oedometer load-back pressure. Unsaturated Soils 2006, 1787-1798.

Tisot, J.P., Aboushook, M., 1983. Triaxial study of swelling characteristics. Proceedings in the 7th Asian Regional Conference on Soil Mechanics and Foundation Engineering, Haifa, Vol. 1, 94-97.

Tripathy, S., Sridharan, A., Schanz, T., 2004. Swelling pressures of compacted bentonites from diffuse double layer theory. Canadian Geotechnical Journal 41, 437-450.

Wileveau, Y., Cornet, F.H., Desroches, J. Blumling, P. 2007. Complete in situ stress determination in an argillite sedimentary formation. Physics and Chemistry of the Earth 32(8-14), 866-878.

Villar, M.V., Lloret, A., 2008. Influence of dry density and water content on the swelling of a compacted bentonite. Applied Clay Science 39, 38-49.

Ye W.M., Cui Y.J., Qian L.X., Chen B. 2009. An experimental study of the water transfer through compacted GMZ bentonite. Engineering Geology 108, 169-176.

Ye, W.M., Chen, Y.G., Chen, B., Wang, Q., Wang, J., 2010, Advances on the knowledge of the buffer/backfill properties of heavily-compacted GMZ bentonite, Eng. Geol. (2010), doi:10.1016/j.enggeo.2010.06.002. 


\section{$1 \quad$ List of Tables}

2

3 Table 1. Tests program

4 Table 2. The swelling pressures of some typical bentonite-based backfilling meterials

5 Table 3. The swelling pressures at different suctions

11 Fig. 1. Grain size distribution of the crushed COx claystone powder

12 Fig. 2. Schematic view of the developed constant-volume cell

13 Fig. 3. Schematic view of the pressure sensors: (a) BER-A-58S pressure sensor; (b)

14 standard pressure sensor

15 Fig. 4. Schematic view of the experimental setup using the constant-volume cell

16 Fig. 5. Schematic view of the swelling test using a triaxial press
Fig. 6. Swelling pressure evolution during wetting at different suctions

Fig. 7. Results from the swell-reload and zero-swell tests; (a) changes in vertical swell with time and (b) change in void ratio with applied vertical stress Fig. 8. Results from the adjusted constant-volume test; (a) tests T8-1 and T8-2; (b) test T9; (c) test T10.

Fig. 9. SEM pictures, (a) as-compacted specimen at a dry unit mass of $2.0 \mathrm{Mg} / \mathrm{cm}^{3}$ and (b) specimen wetted under constrained-volume condition Fig. 10. Pore size distribution curves of as-compacted and wetted specimens 


\section{Tables}

Table 1. Tests program

\begin{tabular}{|c|c|c|c|c|c|c|}
\hline Test method & $\begin{array}{l}\text { Test } \\
\text { No. }\end{array}$ & $\begin{array}{l}\text { Initial } \\
\text { content } / \%\end{array}$ & water & Apparatus & $\begin{array}{l}\text { Specimen } \\
\text { size/mm }\end{array}$ & Wetting condition \\
\hline \multirow{5}{*}{ Constant-volume } & $\mathrm{T} 1$ & 2.8 & & Fig. 4 & $\begin{array}{l}H=10 \\
D=70\end{array}$ & $\begin{array}{l}\text { Suction controlled: } \\
s=57,38,9 \text {, and } 0 \\
\mathrm{MPa}\end{array}$ \\
\hline & $\mathrm{T} 2$ & 2.8 & & Fig. 4 & $\begin{array}{l}H=10 \\
D=70\end{array}$ & $\begin{array}{l}\text { Suction controlled: } \\
s=57 \text { and } 38 \mathrm{MPa}\end{array}$ \\
\hline & T3 & 2.8 & & Fig. 4 & $\begin{array}{l}\mathrm{H}=10 \\
\mathrm{D}=70\end{array}$ & $\begin{array}{l}\text { Suction controlled: } \\
s=38 \text { and } 0 \mathrm{MPa}\end{array}$ \\
\hline & $\mathrm{T} 4$ & 2.8 & & Fig. 4 & $\begin{array}{l}\mathrm{H}=10 \\
\mathrm{D}=70\end{array}$ & $\begin{array}{l}\text { Suction controlled: } \\
s=9 \text { and } 0 \mathrm{MPa}\end{array}$ \\
\hline & T5 & 2.8 & & Fig. 4 & $\begin{array}{l}\mathrm{H}=10 \\
\mathrm{D}=70\end{array}$ & $\begin{array}{l}\text { Suction controlled: } \\
s=0 \mathrm{MPa}\end{array}$ \\
\hline Swell-reload & T6 & 2.8 & & Fig. 5 & $\begin{array}{l}\mathrm{H}=10 \\
\mathrm{D}=38\end{array}$ & $\begin{array}{l}\text { Injecting distilled } \\
\text { water }\end{array}$ \\
\hline Zero-swell & $\mathrm{T} 7$ & 2.8 & & Fig. 5 & $\begin{array}{l}H=20 \\
D=50\end{array}$ & $\begin{array}{l}\text { Injecting distilled } \\
\text { water }\end{array}$ \\
\hline \multirow{3}{*}{$\begin{array}{l}\text { Adjusted } \\
\text { constant-volume }\end{array}$} & $\begin{array}{l}\text { T8-1 } \\
\text { T8-2 }\end{array}$ & 2.8 & & Fig. 6 & $\begin{array}{l}\mathrm{H}=20 \\
\mathrm{D}=50\end{array}$ & $\begin{array}{l}\text { Injecting distilled } \\
\text { water }\end{array}$ \\
\hline & T9 & 2.8 & & Fig. 6 & $\begin{array}{l}H=20 \\
D=50\end{array}$ & $\begin{array}{l}\text { Injecting distilled } \\
\text { water }\end{array}$ \\
\hline & $\mathrm{T} 10$ & 6.4 & & Fig. 6 & $\begin{array}{l}\mathrm{H}=20 \\
\mathrm{D}=50\end{array}$ & $\begin{array}{l}\text { Injecting distilled } \\
\text { water }\end{array}$ \\
\hline Materials & \multicolumn{2}{|c|}{ Methods } & \multicolumn{2}{|c|}{$\begin{array}{l}\text { Dry unit mass, } \\
\mathrm{Mg} / \mathrm{m}^{3}\end{array}$} & $\begin{array}{l}\text { Swelling } \\
\text { pressure, MPa }\end{array}$ & References \\
\hline $\begin{array}{l}\text { FoCa } \\
\text { bentonite/pellet }\end{array}$ & \multicolumn{2}{|c|}{ Constant-volume } & 1.6 & & $3.0-3.5$ & $\begin{array}{l}\text { Maugis and Imbert } \\
\text { (2007) }\end{array}$ \\
\hline $\begin{array}{l}\text { FEBEX } \\
\text { bentonite/pellet }\end{array}$ & \multicolumn{2}{|c|}{ Constant-volume } & 1.5 & & $2.3-3.0$ & $\begin{array}{l}\text { Hoffmann et al. } \\
(2007)\end{array}$ \\
\hline FEBEX bentonite & \multicolumn{2}{|c|}{ Constant-volume } & 1.7 & & $9.0-13.0$ & $\begin{array}{l}\text { Villar and Lloret } \\
\text { (2008) }\end{array}$ \\
\hline MX80 bentonite & \multirow{2}{*}{\multicolumn{2}{|c|}{$\begin{array}{l}\text { Constant-volume } \\
\text { Constant-volume }\end{array}$}} & 1.6 & & $5.1-5.8$ & Dueck (2008) \\
\hline GMZ bentonite & & & 1.7 & & $4.0-4.5$ & Ye et al. (2010) \\
\hline
\end{tabular}

Table 3. The swelling pressures at different suctions

\begin{tabular}{|c|c|c|c|c|}
\hline Test No. & $s=57 \mathrm{MPa}$ & $s=39 \mathrm{MPa}$ & $s=9 \mathrm{MPa}$ & $s=0 \mathrm{MPa}$ \\
\hline
\end{tabular}




\begin{tabular}{ccccc}
\hline $\mathrm{T} 1$ & $0.17 \mathrm{MPa}$ & $0.31 \mathrm{MPa}$ & $0.81 \mathrm{MPa}$ & $1.08 \mathrm{MPa}$ \\
$\mathrm{T} 2$ & $0.17 \mathrm{MPa}$ & $0.33 \mathrm{MPa}$ & $/$ & $/$ \\
$\mathrm{T} 3$ & $/$ & $0.24 \mathrm{MPa}$ & $/$ & $0.99 \mathrm{MPa}$ \\
$\mathrm{T} 4$ & $/$ & $/$ & $0.54 \mathrm{MPa}$ & $0.97 \mathrm{MPa}$ \\
$\mathrm{T} 5$ & $/$ & $/$ & $/$ & $0.82 \mathrm{MPa}$ \\
\hline
\end{tabular}




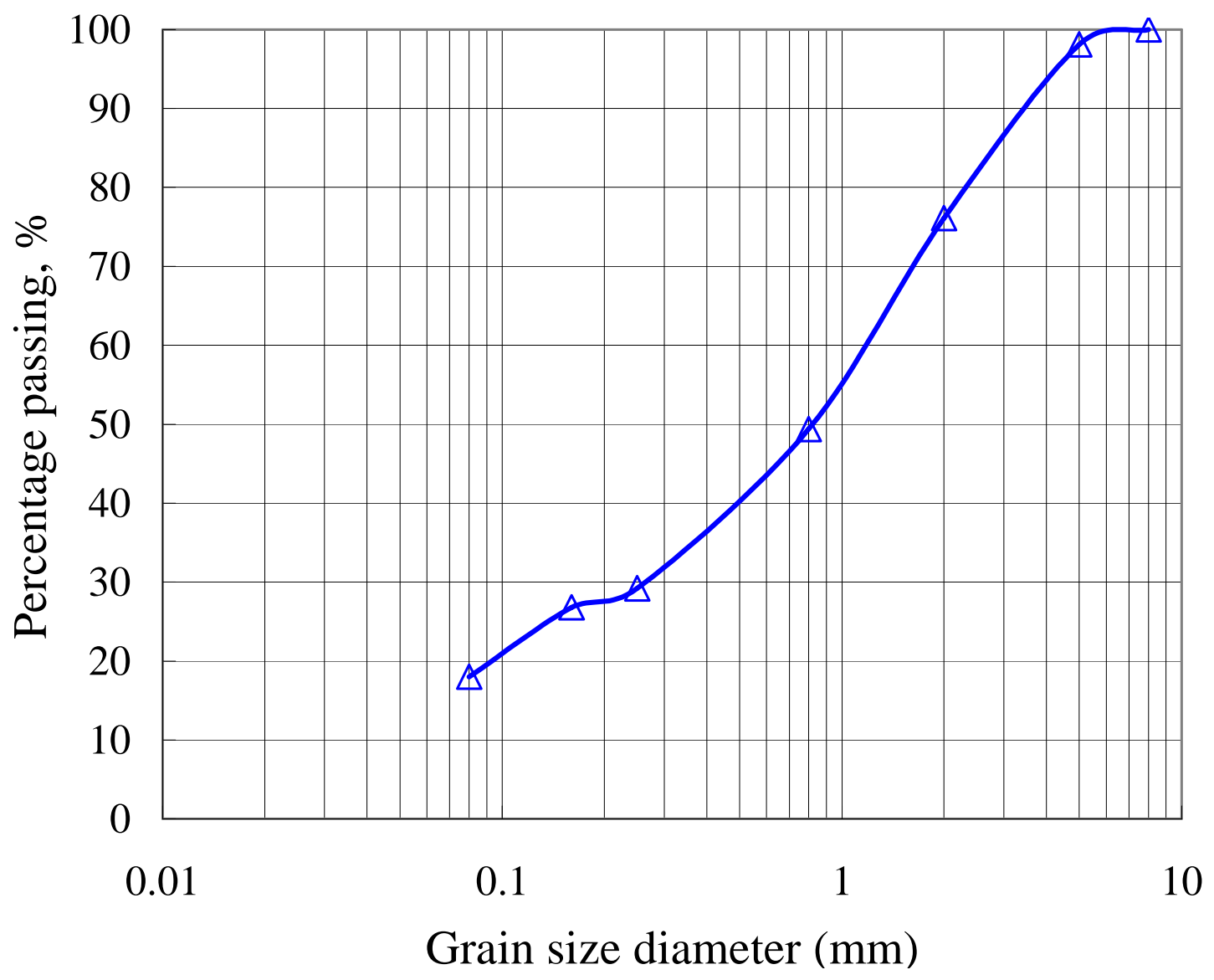

Fig. 1. Grain size distribution of the crushed COx claystone powder 


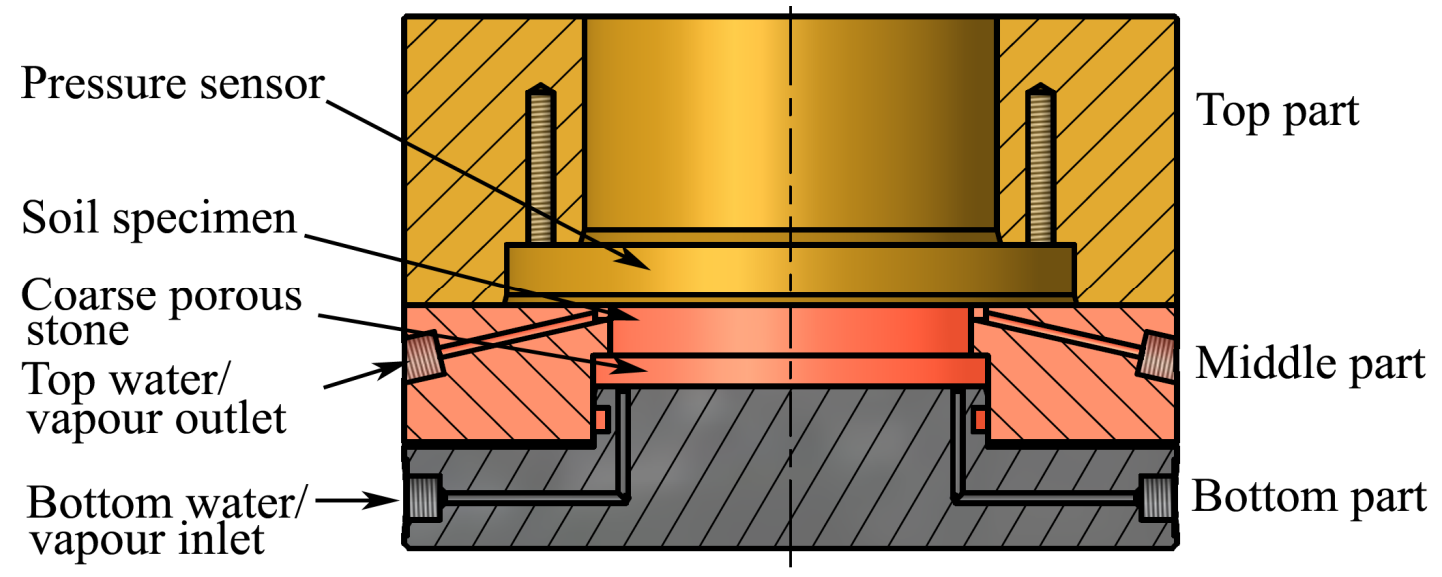

Fig. 2. Schematic view of the developed constant-volume cell 


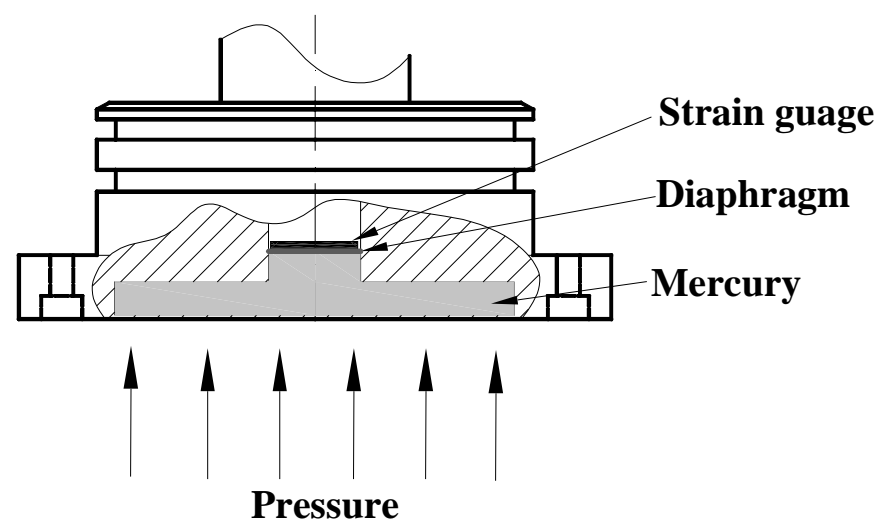

(a)

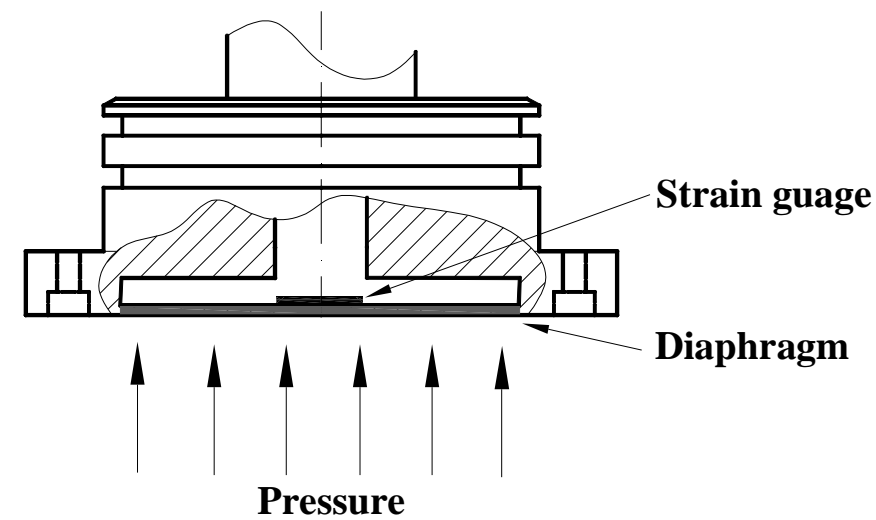

(b)

Fig. 3. Schematic view of the pressure sensors: (a) BER-A-58S pressure sensor; (b) standard pressure sensor 


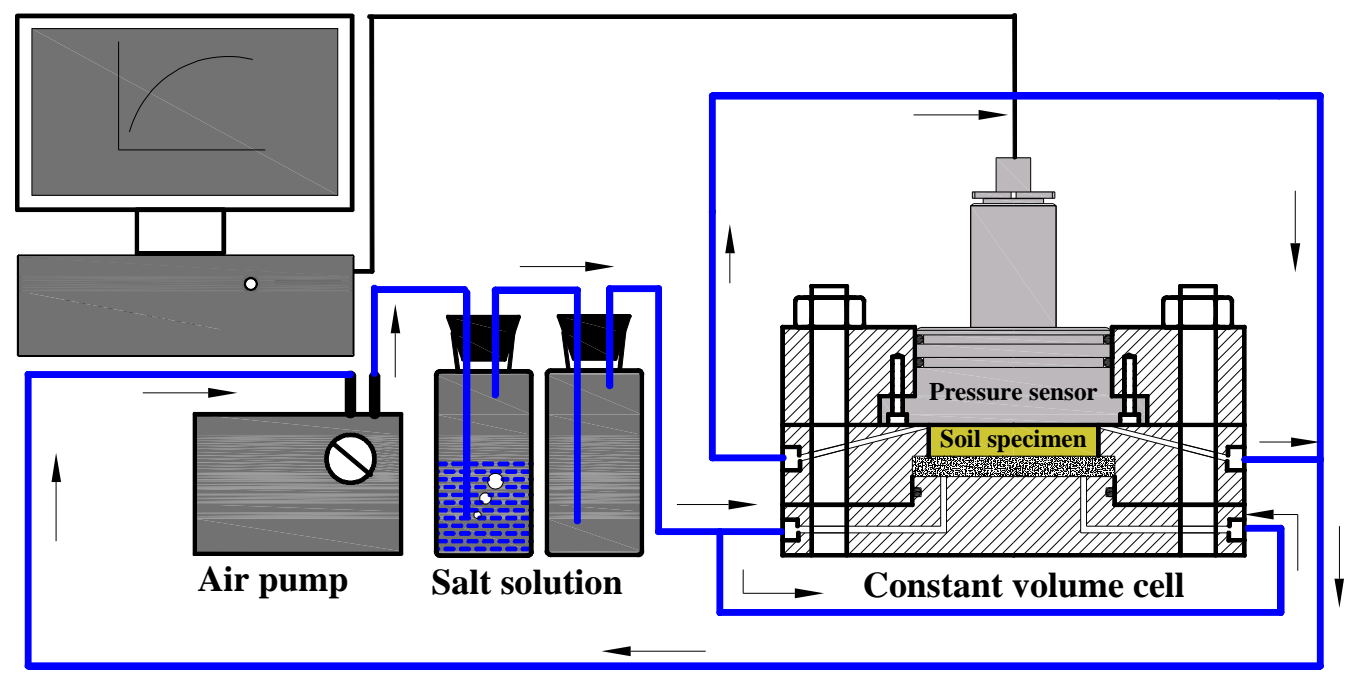

Fig. 4. Schematic view of the experimental setup using the constant-volume cell 


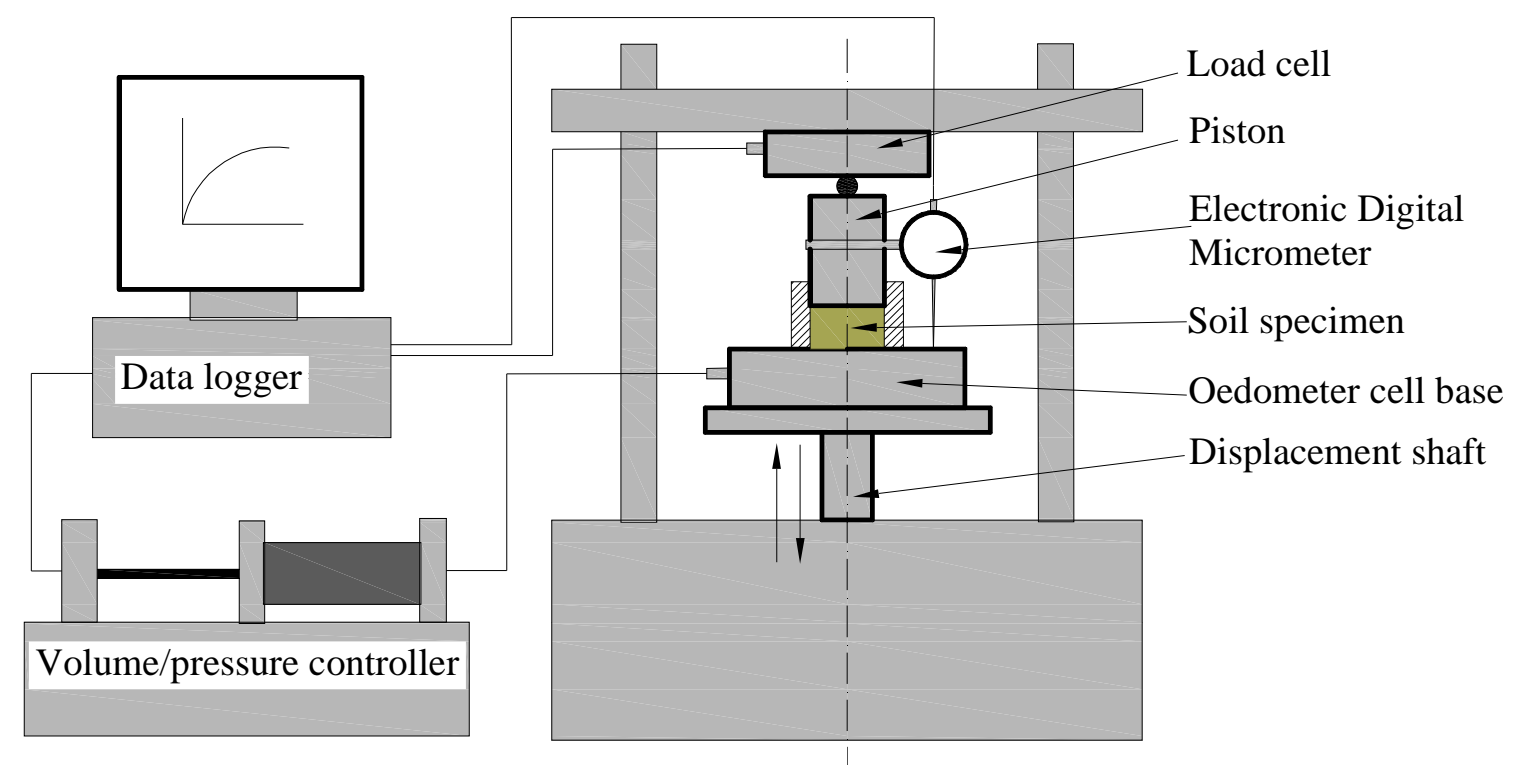

Fig. 5. Schematic view of the swelling test using a triaxial press 

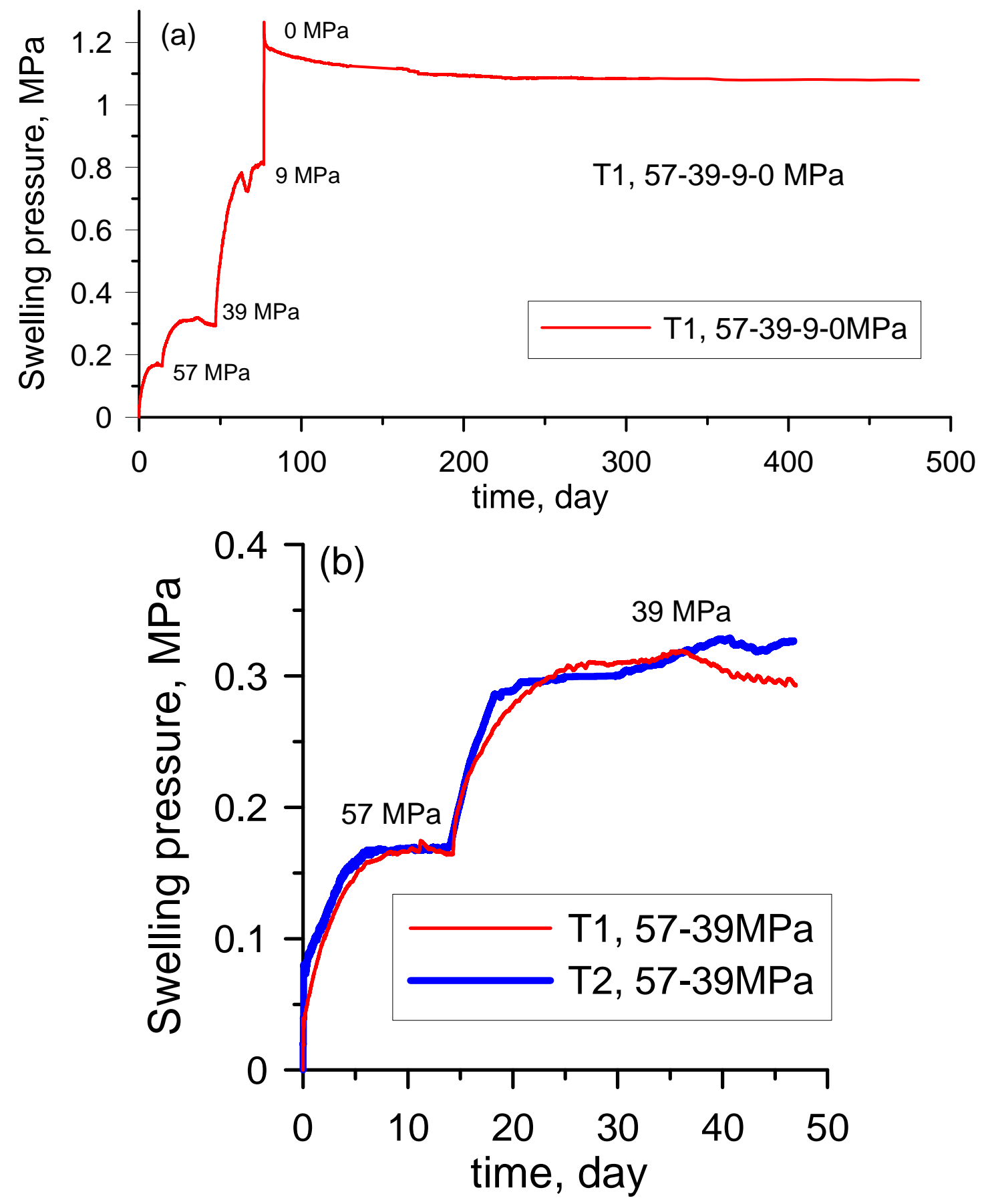

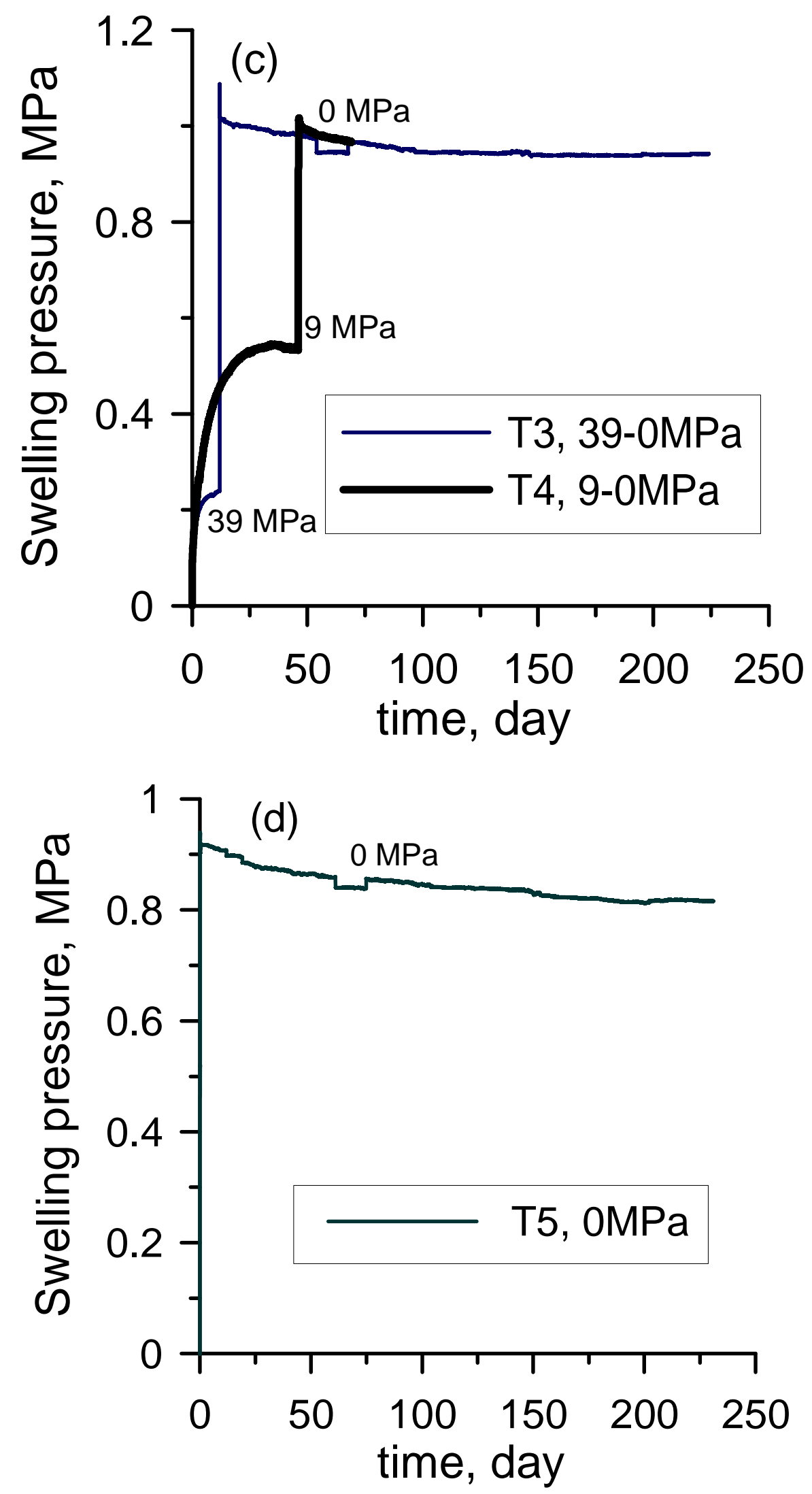

Fig. 6. Swelling pressure evolution during wetting at different suctions 


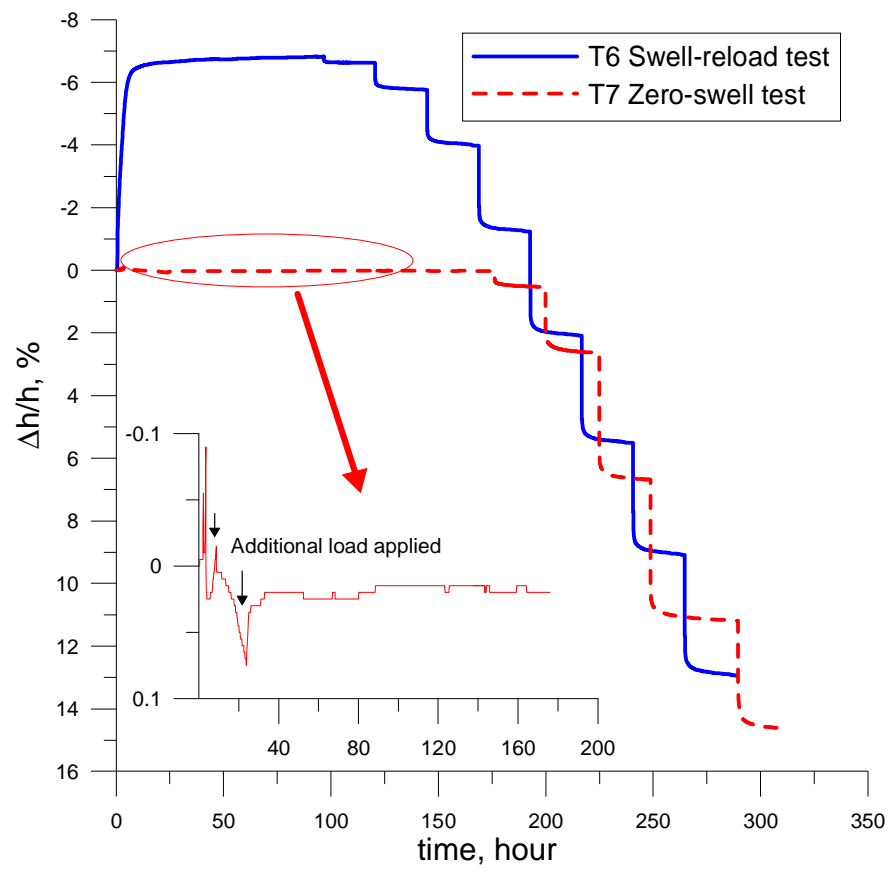

(a)

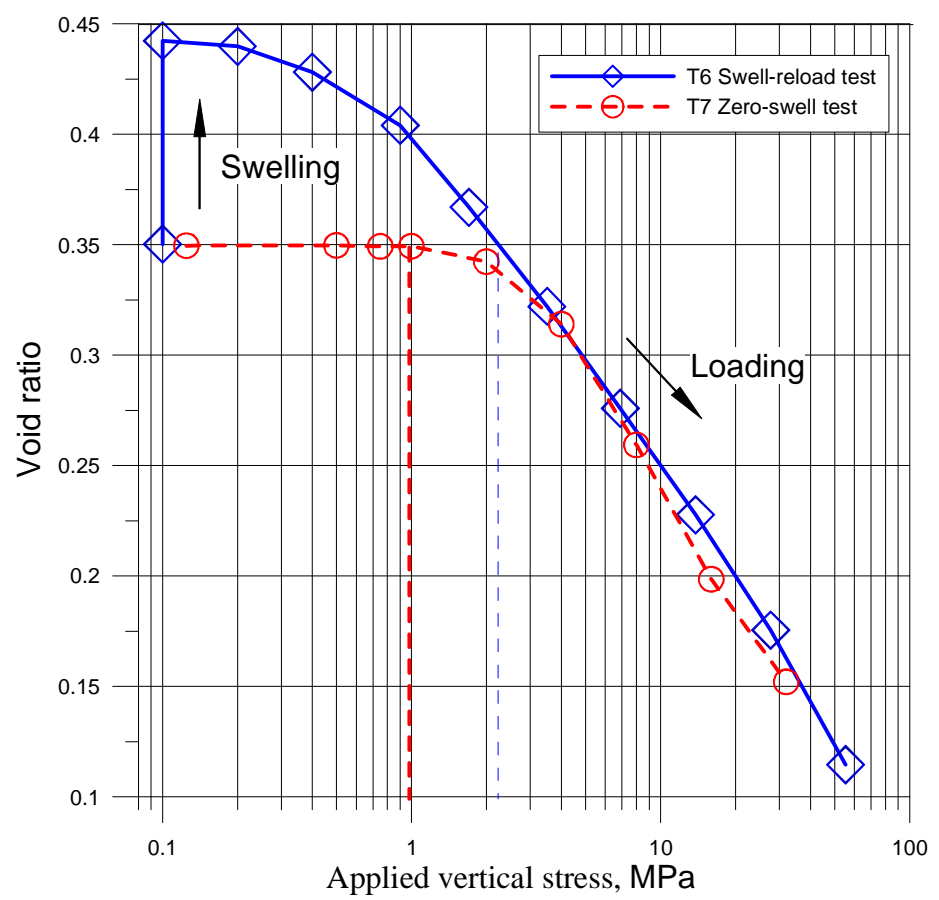

(b)

Fig. 7. Results from the swell-reload and zero-swell tests; (a) changes in vertical swell with time and (b) change in void ratio with applied vertical stress 

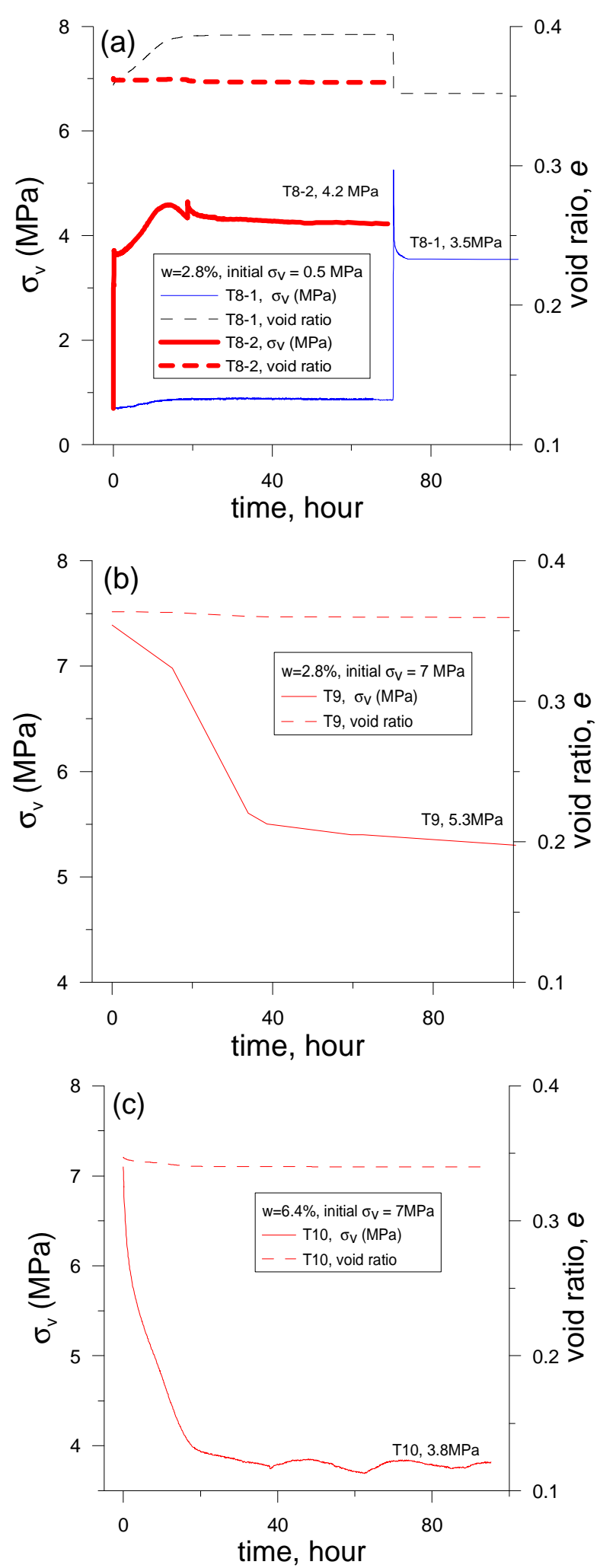

Fig. 8. Results from the adjusted constant-volume test; (a) tests T8-1 and T8-2; (b) test T9; (c) test T10. 


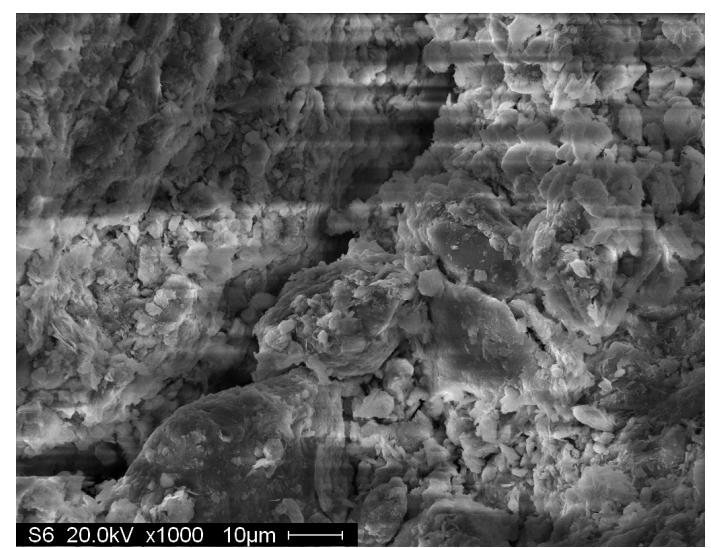

(a)

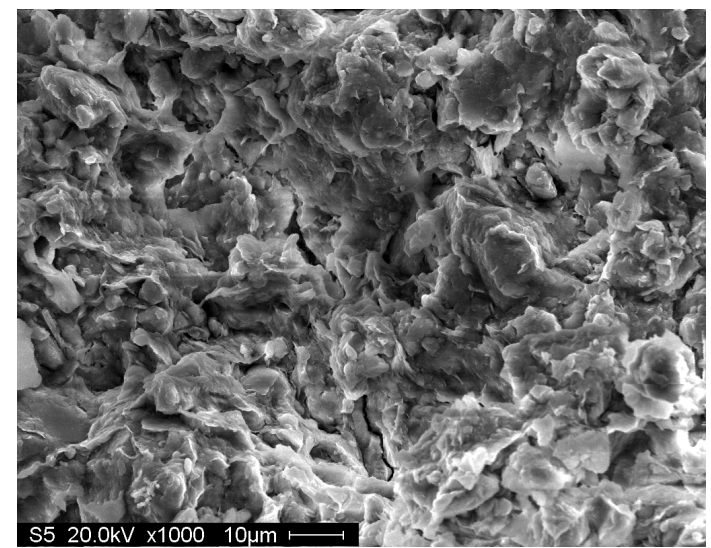

(b)

Fig. 9. SEM pictures, (a) as-compacted specimen at a dry unit mass of $2.0 \mathrm{Mg} / \mathrm{cm}^{3}$ and (b) specimen wetted under constrained-volume condition 
2

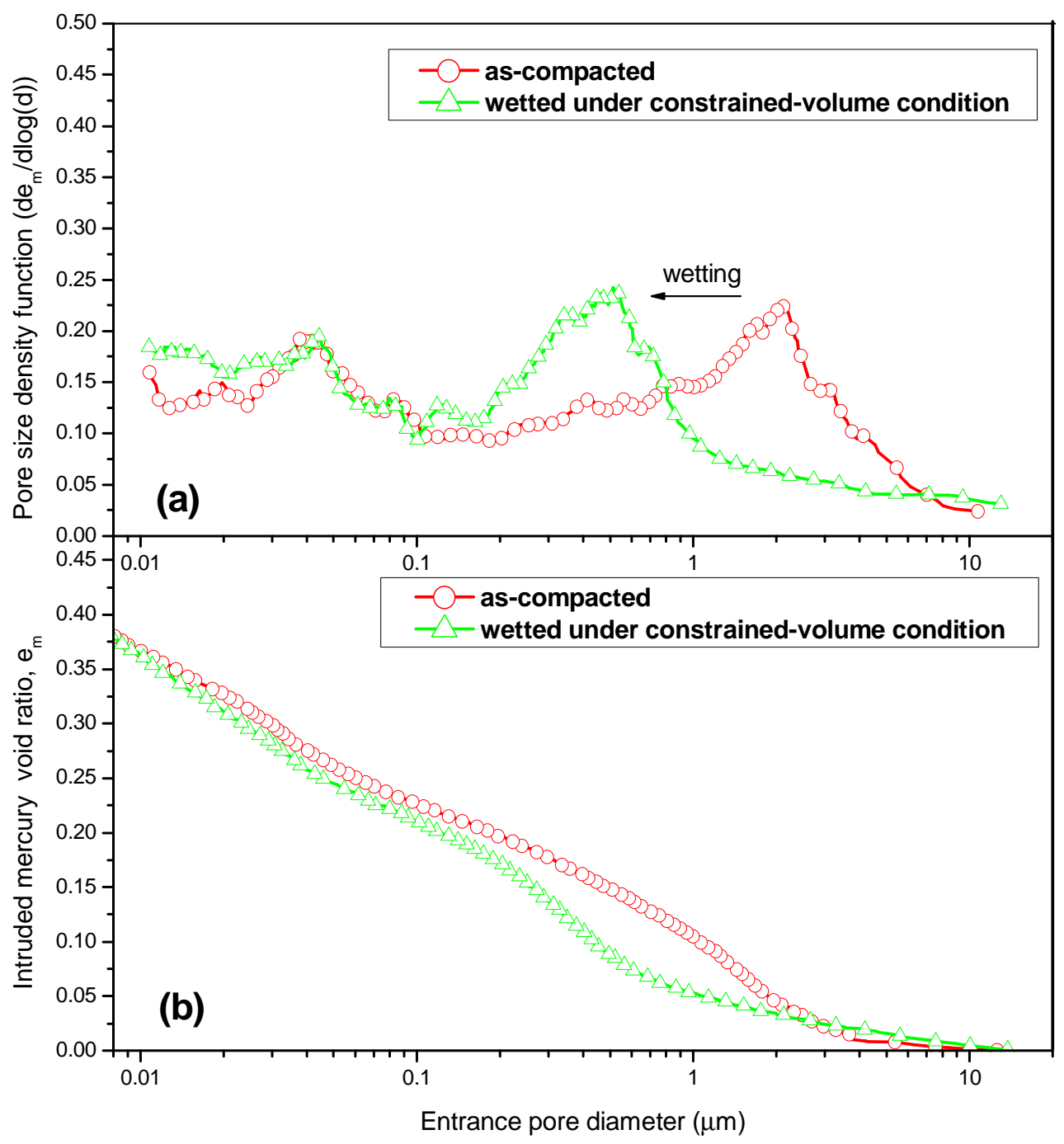

4 Fig. 10. Pore size distribution curves of as-compacted and wetted specimens 